\title{
The ECONOMIC AND ENVIronmental EFFECTS OF A CARbon TAX in SOUTh Africa: A Dynamic CGE Modelling Approach
}

\author{
Jan van Heerden $^{1^{*}}$, James Blignaut ${ }^{1,2}$, Heinrich Bohlmann ${ }^{1}$, Anton Cartwright ${ }^{3}$, Nicci \\ Diederichss $^{4}$ and Myles Mander ${ }^{4}$ \\ ${ }^{1}$ Department of Economics, University of Pretoria \\ ${ }^{2}$ South African Environmental Observation Network, Pretoria \\ ${ }^{3}$ African Centre of Cities, University of Cape Town \\ ${ }^{4}$ Futureworks Consulting \\ Accepted September 2016
}

\begin{abstract}
South Africa's National Treasury released its Carbon Tax Policy Paper in May 2013. The paper proposed a $\mathrm{R} 120 / \mathrm{tCO}_{2}$-equiv. levy on coal, gas and petroleum fuels. Here, we model the possible impacts of such a tax on the South African economy using the computable general equilibrium (CGE) 53-sector model of the University of Pretoria's Department of Economics. The model shows that the carbon tax has the capacity to decrease South Africa's greenhouse gas (GHG) emissions by between $1900 \mathrm{MtCO}_{2}$-equiv. and $2300 \mathrm{MtCO}_{2}$-equiv. between 2016 and 2035. The extent of emissions reductions is most sensitive to the rate at which tax exemptions are removed. Recycling of carbon tax revenue reduces the extent of emissions reductions due to the fact that economic growth is supported. The manner in which carbon tax revenue is recycled back into the economy is therefore important in terms of the extent of emissions reductions achieved, but not as significant as the influence of different exemption schedules. The model shows the carbon tax to have a net negative impact on South Africa's gross domestic product (GDP) relative to the baseline under all exemption regimes and all revenue recycling options assessed. The negative impact of the carbon tax on GDP is, however, greatly reduced by the manner in which the tax revenue is recycled. Recycling in the form of a production subsidy for all industries results in the lowest negative impact on GDP.
\end{abstract}

Key words: computable general equilibrium, UPGEM, carbon tax

JEL: 668

No one is going to win the Nobel Prize in economics for finding the solution to climate change.

The economist who came up with it died a decade before the first prize was given out. Arthur

C. Pigou identified the general problem and the solution - what's by now known as

"Pigouvian taxes". The correct - the only correct - approach is to price each and every ton of carbon according to the damage it causes.

Gernot Wagner \& Martin L. Weitzman

\section{$1 \quad$ Introduction}

South Africa's National Treasury released a Carbon Tax Policy Paper for public comment in May 2013 (National Treasury, 2013). The paper, an update of a discussion paper released in December 2010, described in detail one of South Africa's efforts to respond to anthropogenic climate change and transition to a green economy. In December 2015, National Treasury published the Draft Carbon Tax Bill which represents one of the steps before implementation of the tax. In this paper, we estimate the economy-wide effects of the carbon tax, as described by the National Treasury $(2013,2015)$.

The carbon tax aims to change the behaviour of firms, incentivising them to shift towards cleaner technology when replacing/renewing machinery, technology or processes. The carbon tax will bring the price of carbon closer to its true social cost. This Pigouvian approach is widely regarded by economists as a legitimate way to address the externality problem (Stern, 2008; Wagner \& Weitzman, 2015). To ensure that South Africa transitions to a low-carbon, climate- 
resilient economy in a cost-effective and economically efficient manner, it is important that the trade-offs between inclusive economic growth, poverty alleviation, job creation, and the lowering of GHG emissions are effectively managed. Hence, given the developmental challenges that South Africa has to deal with and the internationally accepted common but differentiated responsibilities and respective capabilities principle (CBDR-RC) that requires more developed countries to make a greater effort to reduce global GHG emissions, South Africa's carbon tax should be gradually phased in.

Various economic modelling techniques to estimate the impact of a carbon tax have been used (see Van Heerden et al., 2006; 2008; Pauw, 2007; Kearney, 2008; Devarajan, Go, Robinson \& Thierfelder, 2009; Alton et al., 2014). Van Heerden et al. (2006) found a "triple dividend" if environmental taxes were recycled through a reduction in food prices. This landmark study used a comparative-static CGE model of South Africa which would later come to be known as the University of Pretoria General Equilibrium Model (UPGEM). Alton et al. (2014) applied a dynamic CGE model to evaluate the impacts of a South African carbon tax designed to achieve national emissions reduction targets set for 2025. The authors' main findings highlight the sensitivity of the mode of recycling carbon tax revenues to distributional outcomes and the small loss of welfare induced by the tax even when all benefits are ignored.

In this paper, we improve on the CGE approach used in Van Heerden et al. (2006) by using an updated and dynamic version of UPGEM with a detailed electricity-generation mechanism. We also further the analysis in Alton et al. (2014) by basing our policy simulations on the announced carbon tax rates and exemptions schedule. In general, our analysis supports the main findings in the two aforementioned papers. Our modelling results suggest that a carbon tax with broad sector coverage implemented gradually and complemented by effective and efficient revenue recycling will contribute to significant GHG emission reductions and will have only a marginally negative impact on economic growth over the short term. Over the medium to long term, the carbon tax will support the transition to a more sustainable low-carbon economy and green jobs.

\section{Methodology and database}

A modified version of UPGEM was applied to conduct an analysis of the South African carbon tax. UPGEM is a CGE model of South Africa developed by staff at the University of Pretoria in collaboration with the Centre of Policy Studies (CoPS) in Melbourne, Australia. UPGEM has been used in a variety of studies over the last decade, including those of Van Heerden et al. (2006) and Bohlmann, Dixon, Rimmer and Van Heerden (2015). The theoretical structure of UPGEM is similar to the MONASH model developed by CoPS and documented in Dixon and Rimmer (2002, 2005) and in Dixon, Koopman and Rimmer (2013). The core UPGEM database is based on the 2011 supply-use (SU) tables published by Statistics South Africa (StatsSA, 2014). A stylised representation of the database is shown in Bohlmann et al. (2015). The modified version of UPGEM used in this study distinguishes 53 industries and products. It includes a more detailed treatment of the electricity sector by allowing up to eight different technologies or types of electricity generation, as illustrated by the nested production structure in Appendix B. It also allows for environmental analysis by linking UPGEM to an external emissions database and adding appropriate theoretical extensions.

Dynamic CGE models such as UPGEM are designed to quantify the effects of a policy change, or exogenous shock, to the economy over a period of time. Given that the database and initial solution to the model are based on 2011 data, 2012 represents the first simulation year. In this analysis, our simulation period extends to 2035, allowing us to evaluate the effect of the carbon tax over a 20-year period (2016-2035) from when it was first imposed. A good way to examine the impacts of an exogenous shock is to compute the differences between a scenario in which the shock has occurred - the policy simulation - and a counterfactual scenario in which the particular shock under examination did not occur - the baseline scenario. Results are then reported as percentage change deviations over time between the first baseline simulation run and the second policy simulation run. 
Following the CoPS style of implementing a CGE model, the general equilibrium core of UPGEM is made up of a linearised system of equations describing the theory underlying the behaviour of participants in the economy. It contains equations describing, amongst others: i) the nature of markets; ii) intermediate demands for inputs to be used in the production of commodities; iii) final demands for goods and services by households; iv) demands for inputs to capital creation and the determination of investment; v) government demands for commodities; and vi) foreign demand for exported goods. The model is implemented and solved using the General Equilibrium Modelling Package (GEMPACK) suite of programs described in Harrison and Pearson (1996) and in Horridge, Meeraus, Pearson and Rutherford (2013). GEMPACK eliminates linearisation error by implementing shocks in a series of small steps and updating the database between steps.

The specification of the modified UPGEM implemented in this paper includes enhancements for environmental analysis based on the Monash Multi-Regional Forecasting (MMRF) model of the Australian economy documented in Adams, Dixon, Giesecke and Horridge (2014). UPGEM functions in a similar manner, with the ability to activate several add-ins when required. For MMRF, these add-ins include: i) an energy and gas emissions accounting module, which accounts explicitly for each industry recognised in the model; ii) equations that allow for inter-fuel substitution in electricity generation; and iii) mechanisms that allow for the endogenous take-up of various abatement measures in response to GHG policy measures. MMRF tracks GHG emissions at a detailed level. It breaks down emissions according to emitting agent, emitting region, and emitting activity. UPGEM follows this same strategy, but excludes the regional accounting component due to data limitations.

Emissions derived from the combustion of fuels are modelled as being directly proportional to fuel usage. No allowance is made for the type of technological innovation that would allow, for example, coal-fired electricity generators to emit less GHG per tonne of coal combusted. However, the model does allow for input-saving technological progress. For example, coal-fired electricity generators may reduce the amount of coal burnt per kilowatt-hour of output. This category of technological progress is typically imposed exogenously. Inter-fuel substitution in electricity generation is handled using the "technology bundle" approach of Hinchy and Hanslow (1996), which is also used in other CGE models for energy-analysis applications such as TAIGEM $^{1}$. Non-combustion (or activity-related) emissions are generally modelled as being directly proportional to the output of the related industries. However, in simulating the effects of a carbon tax or some other price-related penalty on emissions, allowance can be made for abatement of non-combustion emissions. The amount of abatement is directly related to the price of carbon. The add-ins to the core model described here have been included and activated in the modified UPGEM model's theoretical structure. South African-specific data underlying the add-ins were then constructed from available data sources to make these components computable.

The energy and emissions database is a critical component of the modified UPGEM. In order to measure the impact of the South African carbon tax, it is necessary for the model to have GHG emissions embedded in the database. This, in essence, implies a vector of $\mathrm{CO}_{2}$ emissions and energy consumption (in terajoule or TJ), per industrial sector. The emissions and energy data used to develop the database for the model are based on Blignaut, Mabugu and Chitiga-Mabugu (2005) and Seymore, Inglesi-Lotz and Blignaut (2014). As described in these papers, a sectoral emissions and energy inventory was developed using emission factors from various South African sources, as well as UNFCCC (United Nations Framework Convention on Climate Change) default factors that resembled the South African DEA-specific emission factors. It should be noted that the database contains no fugitive emissions. The source document for compiling the emissions and energy database is the 2007 energy balance of South Africa published by the Department of Energy, which has been adjusted to 2011 levels using the GDP growth rate over the period. The countrywide emissions level for 2007 was estimated as $503 \mathrm{MtCO}_{2}$-equiv., with the households' portion being $45 \mathrm{MtCO}_{2}$-equiv. This implies industry-wide emissions of $458 \mathrm{MtCO}_{2}$-equiv., which 
compares favourably with the estimate of $433 \mathrm{MtCO}_{2}$-equiv. by the Department of Environmental Affairs (DEA, 2009) for 2000. Our estimate has been adjusted to $514 \mathrm{MtCO}_{2}$-equiv. for industries and $564 \mathrm{MtCO}_{2}$-equiv. for the country as a whole for 2011 , as can be seen in Table 1 . The tax is not levied directly on households, but indirectly through their consumption of commodities; hence the fact that their emissions and energy use are omitted from the database.

Table 1

Summary of emissions and energy use for 2007 and 2011

\begin{tabular}{|l|c|c|c|c|c|c|}
\hline & \multicolumn{3}{|c|}{2007} & \multicolumn{3}{c|}{2011} \\
\cline { 2 - 7 } & Households & Industry & Total & Households & Industry & Total \\
\hline $\mathrm{CO}_{2}$ emissions (Mil ton) & 45 & 458 & $\mathbf{5 0 3}$ & 50 & 514 & $\mathbf{5 6 4}$ \\
\hline Energy use (TJ) & & 6012316 & & & 6735434 & \\
\hline
\end{tabular}

The proposed tax is effectively a fossil-fuel input tax, but one that is levied on industry-specific $\mathrm{CO}_{2}$ emissions. Since the emissions and energy content of fuels vary, the tax has to be applied to fuel use. An emissions and energy database in terms of fuels had to be developed based on the industry-wide consumption levels. This is provided in Table 2. Note that biomass-related emissions and energy use are excluded from the database as they do not represent a fossil fuel; hence the fact that the numbers for total emissions and energy use are less than depicted in Table 1. This exclusion, together with that of households, narrows the tax base by about 15 per cent.

Table 2

Emissions (in Mil ton) and energy use (in TJ) by fuel for various years

\begin{tabular}{|l|c|c|c|c|}
\hline \multirow{2}{*}{} & \multicolumn{3}{|c|}{$\mathbf{2 0 0 7}$} & \multicolumn{2}{c|}{$\mathbf{2 0 1 1}$} \\
\hline Coal & MtCO $_{2}$-equiv. & TJ & MtCO $_{2}$-equiv. & TJ \\
\hline Gas $^{2}$ & 336 & 3517949 & 377 & 1804330 \\
\hline Petroleum & 23 & 353767 & 25 & 2055578 \\
\hline Total & 73 & 1008948 & 82 & 1607768 \\
\hline
\end{tabular}

The disaggregated fuel use by sector is provided in Table A1 in Appendix A. In addition to the fuel use by sector, the information from Table 2 can be used to calculate the effective tax rate when incorporating the published exemption thresholds. This is because a $\mathrm{CO}_{2} / \mathrm{TJ}$ coefficient can be estimated, which is $96 \mathrm{tCO}_{2} / \mathrm{TJ}$ for coal, $64 \mathrm{tCO}_{2} / \mathrm{TJ}$ for gas and $73 \mathrm{tCO}_{2} / \mathrm{TJ}$ for petroleum. The proposed carbon tax rate in 2016 is $\mathrm{R} 120 / \mathrm{tCO}_{2}$, which allows for calculating a $\mathrm{R} / \mathrm{TJ}$ tax rate. Applying the threshold exemption percentages, excluding that of offsets, shown in Table 3 , provides the effective tax rates presented in Table A1. This was done to standardise the unit of measurement and the tax base in TJ, as the tax is a tax on fossil-fuel consumption, yet the tax rate is expressed in $\mathrm{R} / \mathrm{tCO}$. The standardisation in $\mathrm{TJ}$ thus allows for the differences in the emission coefficients of each fuel input. This database therefore allows for sector-specific fuel-consumption levels, fuel- and sector-specific emission factors and intensities, and sector-specific exemption thresholds. The use of an effective tax rate does not imply a change in the tax design, which is based on applying the full marginal tax rate $\left(\mathrm{R} 120 / \mathrm{tCO}_{2}\right.$, increasing at 10 per cent per annum for the first five years, and then linked to inflation thereafter) to the non-exempted emissions or the balance of the tax base. It is important to note that the 2011 energy use in TJ and the 2016 effective tax rates, as provided in Table A1, are exogenous variables. The tax payable in 2016 is endogenously derived by the model by estimating a fuel-use consumption level for 2016, taking into consideration the entire system-wide dynamics of the economy, model design, database, and closure rules as discussed herein. 
Table 3

Proposed tax-free thresholds in respect of emissions

\begin{tabular}{|l|c|c|c|c|c|}
\hline \multicolumn{1}{|c|}{ Sector } & $\begin{array}{c}\text { Basic tax-free } \\
\text { threshold (\%) }\end{array}$ & $\begin{array}{c}\text { Maximum additional } \\
\text { allowance for trade } \\
\text { exposure (\%) }\end{array}$ & $\begin{array}{c}\text { Additional allowance } \\
\text { for process } \\
\text { emissions (\%) }\end{array}$ & $\begin{array}{c}\text { Total (\%) } \\
\text { (Col. 5) }\end{array}$ & $\begin{array}{c}\text { Maximum } \\
\text { offset (\%) }\end{array}$ \\
\hline Electricity & 60 & - & - & 60 & 10 \\
\hline Petroleum & 60 & 10 & 10 & 70 & 10 \\
\hline Iron and steel & 60 & 10 & 10 & 80 & 5 \\
\hline Cement & 60 & 10 & 10 & 80 & 5 \\
\hline Glass and ceramics & 60 & 10 & 10 & 80 & 5 \\
\hline Chemicals & 60 & 10 & - & 70 & 10 \\
\hline Pulp and paper & 60 & 10 & - & 70 & 10 \\
\hline Sugar & 60 & 10 & 40 & 100 & 0 \\
\hline Agriculture, forestry and land use & 60 & - & 40 & 100 & 0 \\
\hline Waste & 60 & - & 10 & 80 & 5 \\
\hline Fugitive emissions from coal mining & 60 & 10 & - & 70 & 10 \\
\hline Other & 60 & 10 & & - & 50 \\
\hline
\end{tabular}

Source: National Treasury (2013).

\section{Simulations}

As noted in the previous section, two separate simulations are run so as to isolate and measure the impact of the South African carbon tax. The first establishes a business-as-usual (BAU) baseline forecast of the economy in the absence of the shock under investigation. The second simulation imposes the exogenous shock on the economy - in this case, the introduction of a carbon tax. Subsequent policy scenarios, simulating two revenue recycling options, are also tested. Results quantifying the impact of the shock are typically reported as percentage changes between the values in the baseline run and the policy run for each variable, although some variables, such as changes to the budget deficit or net foreign liabilities, may be reported as ordinary changes.

The forecast and policy simulations are done with different closures to the model. In the forecast closure, we exogenise variables for which there is forecast information, such as household consumption, and endogenise variables that are related to them, such as the average propensity to consume (APC). Perturbing the model with the forecasted value of household consumption would give a resulting value for the APC. If we then change the closure by making household consumption endogenous and the APC exogenous, we would get the same value for household consumption by perturbing the value of the APC by the solution value found previously. Therefore, in general, we do a baseline forecast of the economy, change the closure of the model to the policy closure that will be used later in the policy simulation, and regenerate the baseline forecast with it. From there, we are ready to apply any set of additional policy shocks to the exogenous variables. If a policy simulation in which there were no additional shocks was applied to the policy variables, the original baseline forecast values would be the result of the simulation. This makes it legitimate to interpret differences between results in the policy and baseline runs as the effects of the policy shocks.

\subsection{Baseline forecast}

The baseline forecast shows the macroeconomic projections for the main components of GDP from the expenditure side based on International Monetary Fund (IMF, 2016), National Treasury (2016) and CEPII (2012) estimates. Baseline projections paint a BAU picture of the economy without the policy change or shock under investigation.

The BAU baseline projection allows us to run the various policy scenarios simulating the impact of the carbon tax against the baseline and to estimate the deviation from it caused by the tax. From the given forecast values, we find that cumulative real GDP growth of 86.5 per cent is 
predicted for the 24-year simulation period between 2011 and 2035, taking into consideration historical data between 2012 and 2015. This is equivalent to an average annual growth in real GDP of around 2.6 per cent over the forecast period, with an average of 3 per cent forecast for the period from 2019 to 2035 .

Figure 1 shows the macroeconomic projections for selected macro variables generated in the baseline forecast in year-on-year percentage change terms. Figure 2 shows the macroeconomic projections for GDP from the income side, specifically in cumulative percentage change terms, relative to 2011. Apart from increases in capital and labour, real GDP growth is also generated through technical progress or productivity gains. Given the growth in capital and labour projected over the forecast period, and taking into consideration that each contributes roughly half of gross value added (GVA) at factor cost, we find that technical-change improvements contributing to around 28 per cent of the projected GDP growth should be generated. We have made conservative estimates regarding employment growth. Employment is forecast to rise in line with population growth, thereby leaving the unemployment rate virtually unchanged. Inflation is forecast to remain within the inflation target range, rising at an average of 5.6 per cent per annum over the forecast period.

Figure 1

Macroforecasts for 2012 to 2035 (year-on-year percentage change)

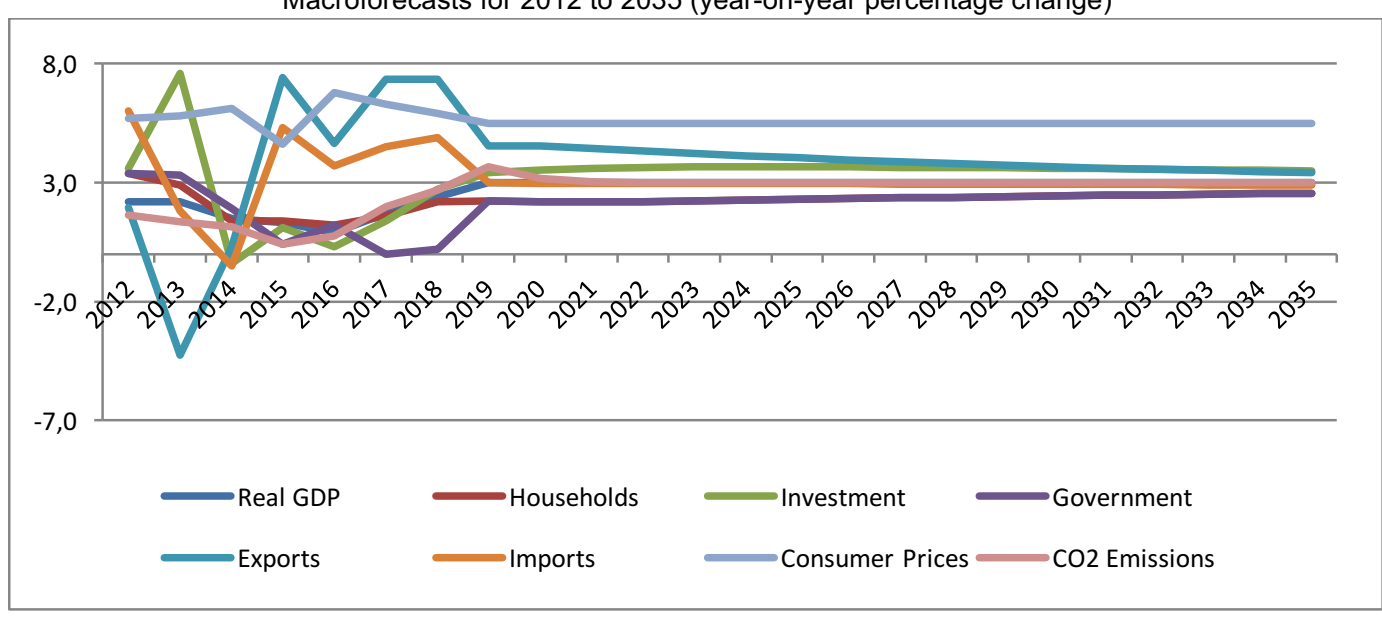

Figure 2

Macroforecasts for 2012 to 2035 (cumulative percentage change)

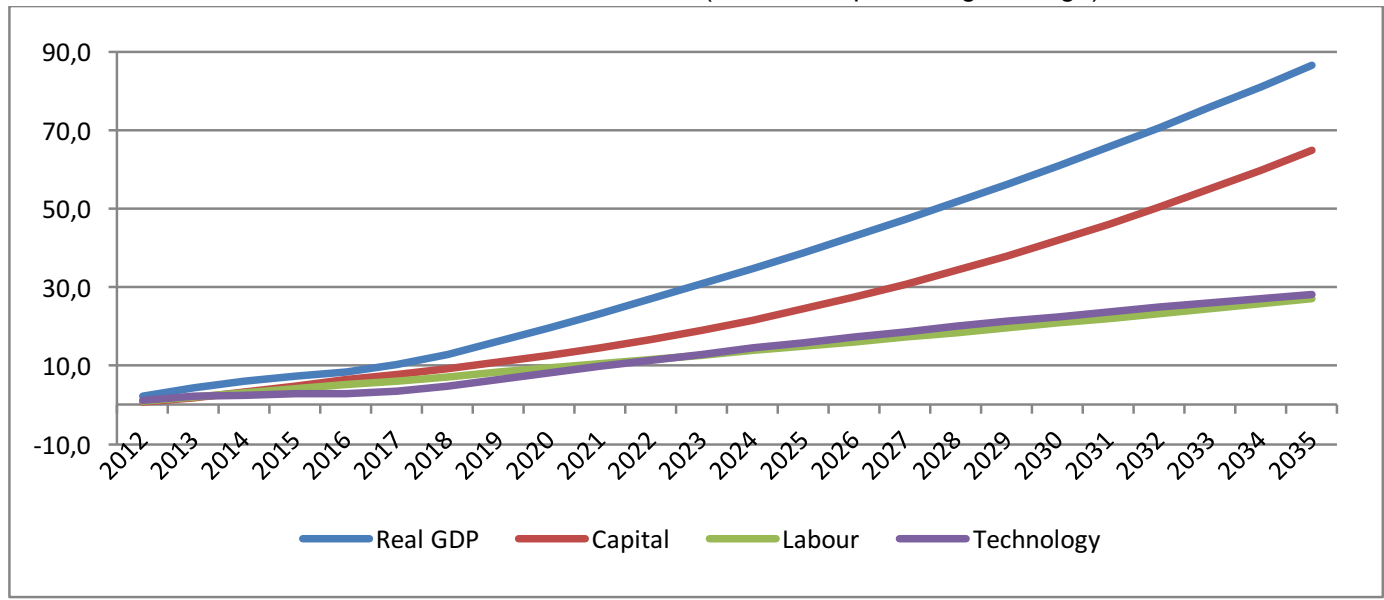


On an industry level, we find that industry output typically follows the performance of the main macrovariable with which it has the closest association. Primary and secondary industries which are export-intensive, such as mining and selected manufacturers, are therefore expected to perform in line with projected export growth. Similarly, the construction industry's fortunes are closely tied to projections concerning investment growth in the baseline.

For the purpose of this baseline forecast, no explicit assumptions were made regarding future improvements to efficiency and cost competitiveness of clean technologies relative to fossil fuelbased sources in the electricity-generation mix. The ratio of each electricity-generation technology relative to total electricity generation is assumed to remain fixed in the baseline relative to 2014 values. Subsequently, $\mathrm{CO}_{2}$ emissions are forecast to rise in line with real GDP. This is a simple BAU baseline designed solely to help isolate and measure the impact of the proposed carbon tax as an instrument towards achieving government's desired generation mix and carbon emission targets. BAU baseline assumptions can easily be tweaked to incorporate future expectations regarding cost and efficiency of different technologies, but, to establish an initial benchmark, we assumed the status quo to be maintained in this particular baseline forecast simulation.

We do not consider any of the IRP Update (DoE, 2013) generation-mix options in our BAU baseline. The emissions cap targeted by policymakers and subsequent shadow price built into the IRP Update baseline scenarios make it difficult to assess what the impact of a carbon tax alone would be. Analysis presented in the IRP Update suggests that the carbon tax is too low to make any tangible difference to the optimal generation mix given the emissions limit of 275MT per annum and indirect carbon price it imposes on the economy. However, that outcome is contingent on various cost-competitiveness assumptions, especially regarding renewable technology, which have changed considerably since 2013. It should also be kept in mind that the IRP Update modelling was done through a suite of energy models, whereas the analysis in this study is conducted with a CGE model linked to a carbon emissions database. We believe that imposing a carbon tax on the BAU baseline specified here is likely to yield the most accurate reflection of the impact of the tax on the overall economy and of the behavioural changes it may lead to. However, given that the generation mix and build programme are likely to be very different from that specified in our baseline, with or without the proposed carbon tax, results from the policy simulations should not be used to estimate the level of carbon emissions in the economy after the imposition of the tax, unless great care is taken. Instead, we advise that the focus of our policy results remain only the percentage change deviation, relative to the baseline path, caused by the carbon tax.

\subsection{Policy scenarios}

In this section, the results from the modelled impact of the proposed carbon tax on South Africa's GDP and total carbon emissions as well as some specific industries that might be more vulnerable than others are discussed. The tax revenue is also recycled back into the economy in two ways such that the government budget stays constant or revenue-neutral, and we compare the different outcomes. Furthermore, as alternative scenarios, the proposed first five years' tax exemptions are phased out over the forecast period and the differences between the taxes with and without exemptions are discussed. The results are reported as percentage deviations from the baseline described above.

\subsubsection{Design of the tax policy scenarios}

South Africa's economy has historically been dependent on coal as both an important mining subsector and more generally as a source of liquid fuel and the predominant feedstock for the national electricity grid. Dependence on coal constitutes a structural economic challenge for the effort to reduce the country's high levels of GHG emissions per unit of GDP. To address this, and in a demonstration of climate change leadership, South Africa committed to making a fair contribution to the global effort to prevent anthropogenic climate change by curtailing its GHG 
emissions through a "peak-plateau-decline" (PPD) emissions trajectory in 2009. The voluntary PPD commitment involves a 42 per cent reduction in GHG emissions by 2025 relative to BAU (DEA 2011a \& b).

The levying of a carbon tax has been mooted by South Africa's National Treasury as one way of influencing energy consumption and investment patterns so as to achieve the PPD targets (National Treasury, 2013) . $^{3}$. To this ends the National Treasury released a Carbon Tax Policy Paper on reducing GHG emissions and facilitating the transition to a green economy in May 2013. The Carbon Tax Policy Paper described in detail the design features of the proposed tax. As a result, it was possible for the first time to model the potential impact of the carbon tax with reference to a proposed policy.

The proposed tax has its theoretical underpinnings in the need to internalise the negative externality of emissions and thereby support a structural transition of the national economy towards a more climate-resilient and less carbon-intensive economy. Both the National Development Plan and South Africa's Green Economy Accord (DED, 2011) highlight that this economy will also be more labour-intensive.

It is hoped that making an "early move" (National Treasury, 2013:16) will provide a competitive advantage for South Africa in accessing new markets that may be about to implement border carbon adjustments (BCAs).

Key design features of the proposed tax include the following:

- The tax is effectively a fossil-fuel input tax levied on Scope 1 emissions, that is, emissions that result from fuel combustion, gasification, and non-energy industrial processes.

- The tax is levied at $\mathrm{R} 120 / \mathrm{tCO}_{2}$-eq, with implementation proposed to commence in 2016 and set to increase by 10 per cent per annum over the first five years (to R175.69 in 2020).

- The tax is applied to the six GHGs accounted for by the UNFCCC $\left(\mathrm{CO}_{2}, \mathrm{CH}_{4}, \mathrm{~N}_{2} \mathrm{O}, \mathrm{PFCs}, \mathrm{SF}_{6}\right.$ and HFCs), although no $\mathrm{SF}_{6}$ or HFC emissions are reported by South African firms.

- Every sector is provided with a basic exemption of 60 per cent of their emissions during the initial five years, but specific sectors may qualify for further exemptions (up to a maximum of 90 per cent) as a result of their structural or technical inability to cut emissions, of the Z-factor allowance as recognition for best performance of firm within the sector, of trade-exposure exemptions and via carbon offsets. The 60 per cent threshold and the exemption categories are to be reviewed after the initial five-year phase. It should be noted that the full marginal tax of $\mathrm{R} 120 / \mathrm{tCO}_{2}$-eq is levied on the non-exempted portion of the emissions.

- In the initial five-year window, it is proposed that agriculture, forestry, waste handling, and land-use activities receive an additional 40 per cent exemption, thereby rendering them completely exempt from the tax. The cement, iron and steel, aluminium and glass sectors are listed as among potential sectors qualifying for a 10 per cent exemption on top of the blanket 60 per cent exemption owing to the inherent structural/technical difficulties these sectors are expected to face in reducing emissions.

- To protect the international competitiveness of South African industry and to prevent carbon leakage through the relocation of firms, a further exemption of up to 10 per cent is available to "trade-exposed" sectors. Trade-intensive industries are defined as those industries in which exports and imports combined make up more than 40 per cent of domestic output. In the initial five-year window, aluminium, iron, glass, ceramics and sugar are among the sectors that might receive up to 10 per cent additional exemption in this period.

- Further reductions in tax exposure of either 5 per cent or 10 per cent are possible through carbon offsets, depending on the sector in which a firm operates. The details of offset arrangements are outlined in a draft offsets paper released for public comment in April 2014 (National Treasury, 2014).

- The maximum tax-free threshold (including the offsets and possible adjustments to the basic 60 per cent tax-free threshold for carbon intensity) is limited to 90 per cent, except for those 
sectors (forestry, agriculture, land use and waste) that have been completely excluded during the first five-year period.

- Revenue from the proposed tax will be recycled via the national fiscus. In keeping with the National Treasury's strategy of retaining fiscal flexibility, the carbon-tax policy paper does not make specific commitments with regard to how the revenue will be recycled, although it lists a number of recycling and tax-shifting options. It is, however, the intention to use the revenue generated to support the structural transition towards a low-carbon economy, to protect poor households from the impact of energy price increases, and to stimulate the green economy. It is beyond the scope of this paper to model the effects of the carbon tax on income distribution or poverty.

The proposed introduction of the carbon tax constitutes a fiscal shock, complete with relative economic "winners and losers". Anticipating the different impacts and distributional effects is one of the outcomes of the modelling exercise and is crucial to the effective implementation of the carbon tax.

\subsubsection{Design of the specific tax policy shocks}

The modelled policy scenarios are based on the proposed carbon taxes on all industries that use coal, gas (including both liquefied petroleum gas (LPG) and natural gas) and petroleum in the production process. In 2016, the rand per terajoule $(\mathrm{R} / \mathrm{TJ})$ tax rates on these fuels equivalent to a carbon tax of $\mathrm{R} 120 / \mathrm{tCO}_{2}$-equiv. is $\mathrm{R} 11472 / \mathrm{TJ}$ on coal, $\mathrm{R} 7$ 647/TJ on gas and R8 707/TJ on petroleum. These are the rates that have been applied before taking into account the various exemptions.

The carbon tax on GHG emissions is initially imposed, taking into account all the suggested exemptions as published in the 2013 Carbon Tax Policy Paper. All the industries pay the R/TJ rates on the fuel inputs as indicated above, but the tax base is reduced by the total percentage of tax-free thresholds (Scenario T1). The tax-free thresholds are then gradually removed by 10 percentage points per annum from 2021 onwards on all industries, until all industries pay the full tax. This implies, for instance, that the petroleum industry's tax rate would take seven years to reach the full rate (from 2021), while the cement industry's tax rate would take eight years to reach the full rate, since they respectively have a 70 and 80 per cent exemption initially (Scenario T2).

For the first five years from 2016, the tax rates are increased by 10 per cent per annum (as per the 2013 Carbon Tax Policy Paper), and, thereafter, by the assumed inflation rate, which is 5.5 per cent per annum over the forecast period in both scenarios T1 and T2.

\subsection{Comparing the effects of the different tax policy shocks}

\subsubsection{Impact on $\mathrm{CO}_{2}$ (without recycling)}

The two sets of tax policy shocks are compared with the baseline forecast by showing the deviations from the baseline in the growth of total $\mathrm{CO}_{2}$ emissions. It is expected that the first tax scenario, with the generous exemptions as set out in Table 3, would have the smallest effect on curbing emissions, while the second scenario, where all the exemptions are gradually phased out, would have the biggest impact on emissions.

In Figure 3, we see exactly these anticipated results: the first set of exemptions has the smallest effect on emissions, while removing all the exemptions has a significant effect: it reduces the increase in emissions by almost 50 per cent. From these results, it can be anticipated that the results of imposing the "carbon taxes" (without considering recycling) are likely to reduce $\mathrm{CO}_{2}$ emissions by between 38.3 per cent (if all exemptions are in place) and 50 per cent by the end of the forecast period (if all exemptions are gradually phased out). 
Figure 3

Cumulative percentage change in $\mathrm{CO}_{2}$ emissions as a result of taxes on fuel inputs (deviation from baseline)

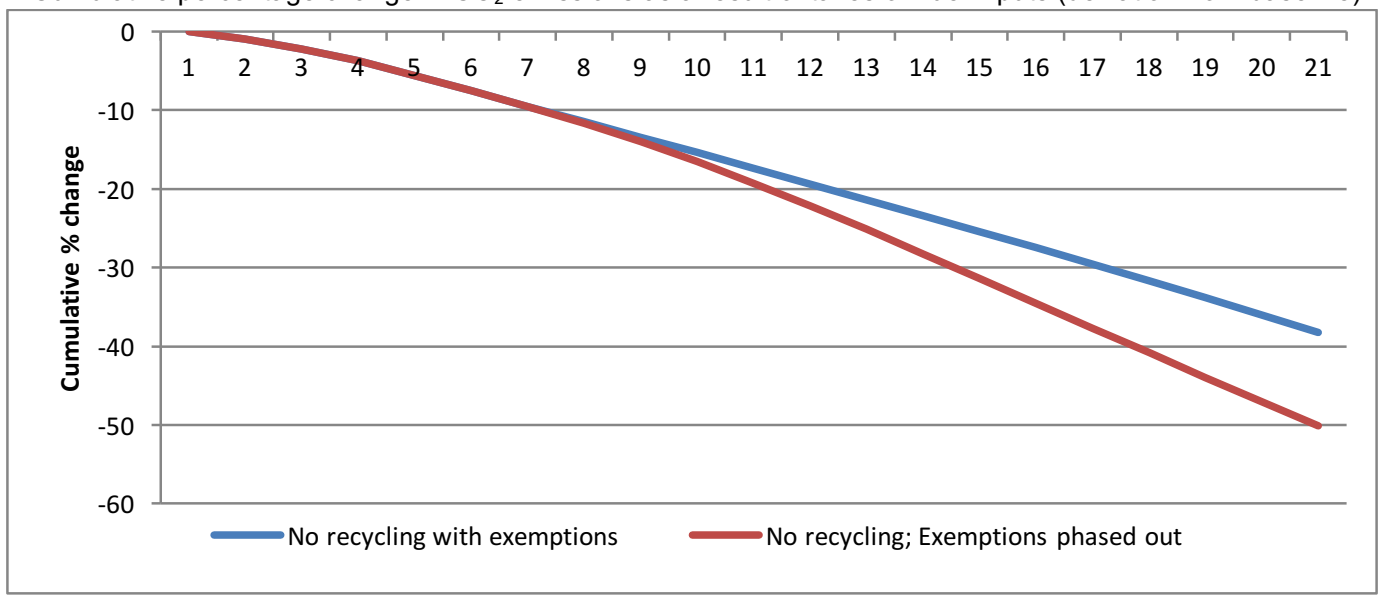

\subsubsection{Impact on GDP (without recycling)}

In Figure 4, the blue line shows that, with the implementation of the carbon tax, but with the 60 to 100 per cent exemptions for the various industries over the forecast period, total real GDP will decrease by 6.4 per cent, relative to the baseline, by 2035. When the exemptions for all industries are phased out from 2022 (purple line), the total real GDP will decrease by 13.7 per cent over the forecast period, relative to the baseline.

Figure 4

Cumulative percentage change in real GDP as a result of taxes on fuel inputs (deviation from baseline)

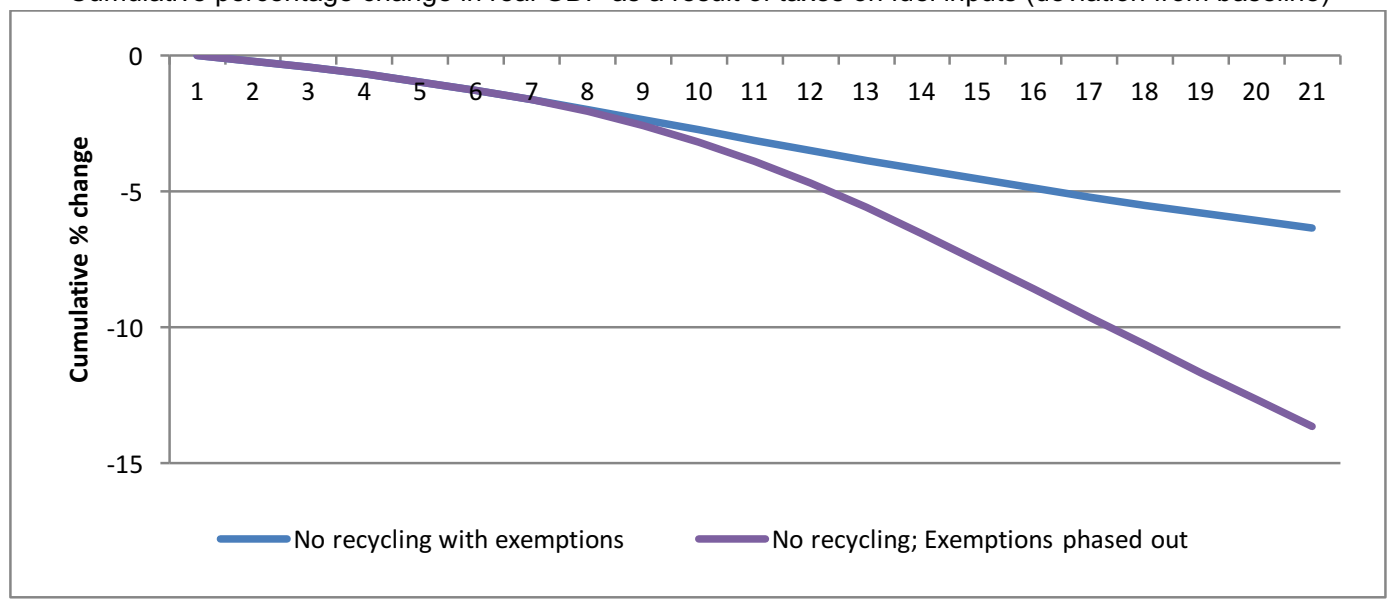

\subsubsection{Sectoral impact (without recycling)}

In this subsection the industry effects of the tax scenario where all the exemptions are phased out for all industries, are compared. Figure 5 shows the respective sectoral impacts of the fuel input tax and discusses some of the results.

The biggest impact on production is on CoalGen, the industry that produces electricity from coal. This is to be expected, because coal forms almost 70 per cent of the industry's intermediate input costs and coal is taxed as one of the four fuel inputs. The next most adversely affected South African industries would be Petroleum Refineries, Coke Oven, Other Manufacturing, and Iron and Steel. The first two are easy to explain in that they use large amounts of coal and crude gas as inputs into their production processes - Petroleum Refineries use 15.5 per cent coal and 18.4 per 
cent crude gas as intermediate inputs, and Coke Oven uses 28.7 per cent coal and 14.1 per cent crude gas. The reason why Iron and Steel and Other Manufacturing are amongst the biggest losers can be found in Figure 6. The carbon tax increases the costs of all industries and hence inflates South African prices relative to the rest of the world. In the process South African industries become less competitive and lose foreign markets for their outputs as they become more expensive. Figure 6 shows that exports of both industries decline by about 30 per cent over the forecast period. This scenario is, of course, predicated on the assumption that South Africa's trading partners do not impose any mode of carbon pricing on their domestic economies.

Figure 5

Industry results of the implementation of a fuel input tax in per cent change deviation from the baseline and with all the tax exemptions phased out except for the agricultural industries (Policy Set 2)

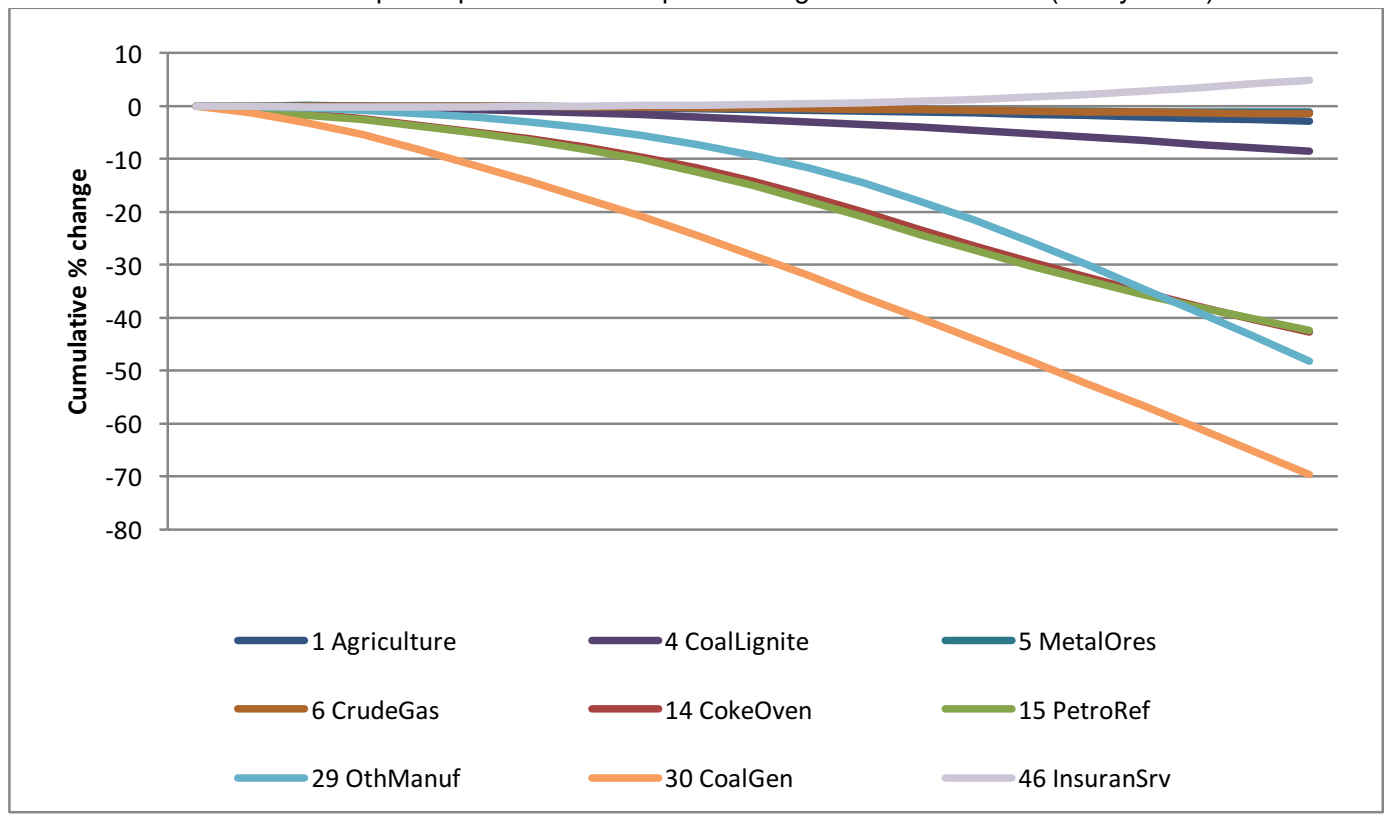

Figure 6

Cumulative percentage change in exports of Iron and Steel and Other Manufacturing (deviation from baseline)

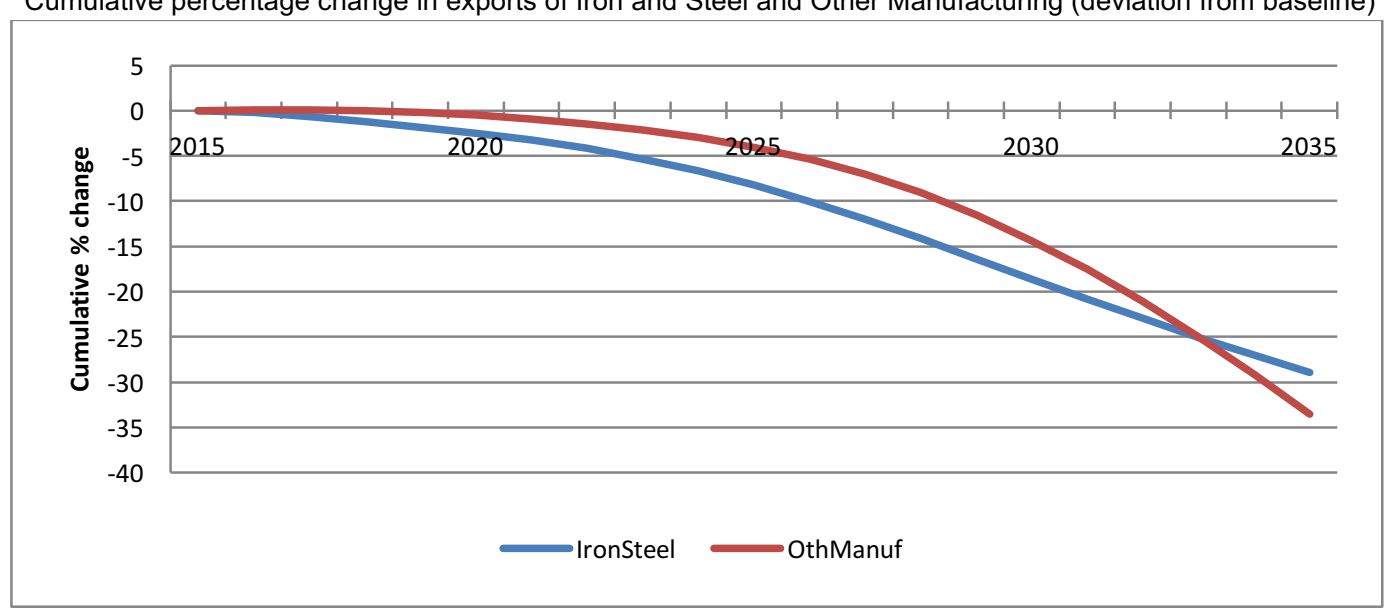




\subsection{Design of the tax recycling schemes}

South Africa, in line with its time-honoured fiscal policy, will not ring-fence the carbon tax revenue for specific projects or sectors. However, a number of revenue recycling initiatives have been highlighted in the policy paper to simulate the outcome of different carbon tax revenue reinvested strategies. The modelling approach used here supports South Africa's planned revenue recycling strategy by identifying those sectors and socio-economic classes that are most likely to be adversely affected by the tax. The model is expected to assist decision makers in striking an appropriate balance between environmental and economic goals.

Similarly, the National Treasury is committed to using the carbon tax revenue in a manner that prevents an exacerbation of South Africa's existing socio-economic inequality, and the model serves as a useful tool in suggesting the extent to which, and how, this might be done.

In the results presented above, fuel input taxes were shown as being levied on all industries when they use fuels as inputs in their production processes, but there was no recycling of the tax revenue back into the economy. This is very unrealistic in that the government would not levy a tax and not spend the revenue. Understandably, the economic effects of such an unrealistic scenario would be a shrinking of total demand in the economy, resulting in a general price decrease (deflation) and lower costs of production. Exports would usually benefit from such economic conditions. Although the revenue collected would not be earmarked for specific expenditures, it is important to choose different channels of revenue recycling in the model and study the different outcomes that the various channels would produce.

The UPGEM model does not contain elaborate government accounts. The government revenue and tax system in the model is primitive, because the model specialises in determining the prices and quantities of industry production of various commodities in its quest to search for new equilibriums after certain shocks have been applied to the model. We apply the recycling of revenue through subsidies or lower taxes on industries or commodities in the model, thereby affecting the price system, rather than on higher levels of spending by the government. Two different revenue recycling schemes were modelled, namely decreasing:

1 the VAT (value-added tax) rate on industries and households, and

2 the power of the tax on intermediate sales to the green-electricity generators and the electricmachinery industry.

When the tax revenue is not recycled, the government runs into a large budget surplus (or a decrease in the deficit). The recycling is effected by keeping the budget surplus (or deficit) fixed at the same level as in the baseline, while allowing one of the two tax variables mentioned above to adjust accordingly.

\subsection{Comparing the effects of the two recycling schemes}

\subsubsection{The effects of the various recycling schemes on real GDP growth}

Figure 7 shows the deviations in real GDP growth from the baseline as a result of the general tax recycling scheme. With the fall in total demand when tax revenue is not recycled, the real GDP falls much below the baseline, as depicted in Figure 5 above. When the revenue is recycled, the size of the deviation from the baseline decreases, as the recycling stimulates some parts of the economy. Figure 7 shows three lines for real GDP deviation from the baseline for the two norecycling cases and the general recycling scenario discussed above.

The results are largely in line with expectations. Recycling through a reduction in the general tax on production takes real GDP almost back to the baseline (brown line). GDP is affected most negatively with the introduction of a new tax without exemptions (purple line). It is affected less severely if the tax is gradually implemented (blue line), and is affected the least when the revenue is recycled again. 
Figure 7

Cumulative percentage change in the impact of imposing carbon taxes on the real GDP of the no-recycling scenarios compared with five recycling scenarios

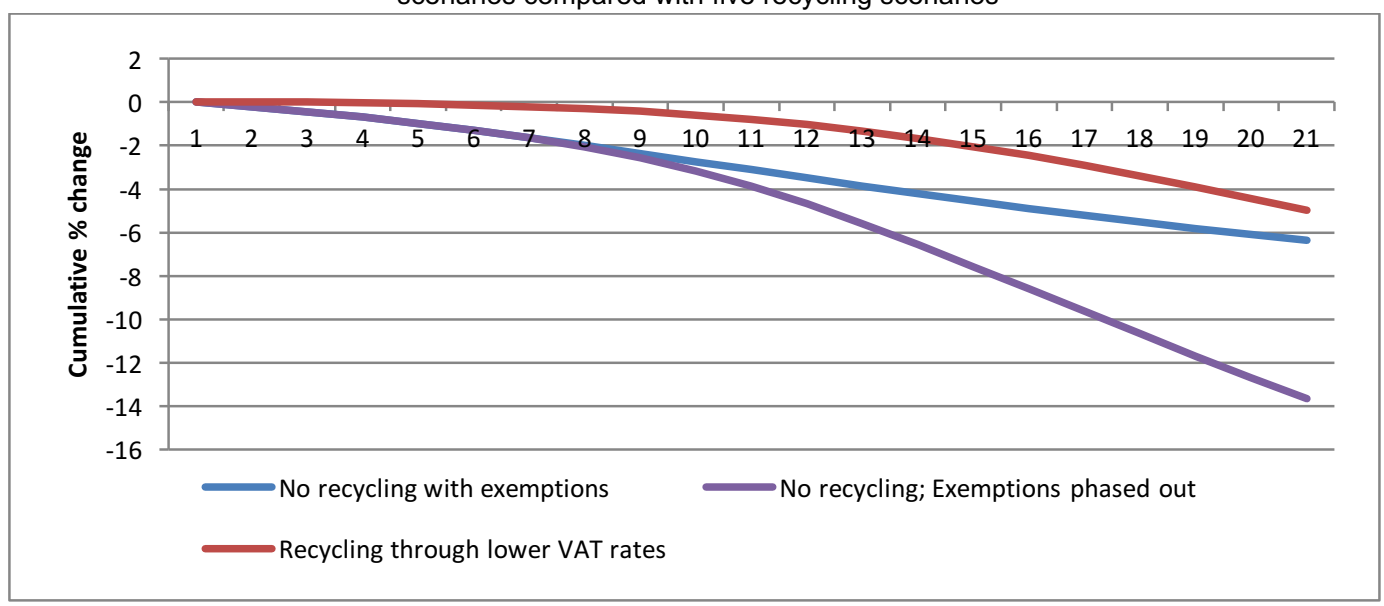

\subsubsection{The effects of the two recycling schemes on carbon emissions}

In Figure 7, the effects of recycling are shown on real GDP growth, relative to the baseline. Although it is important to have a feel for the general effects of recycling schemes, the "negative" effects of the recycling schemes on carbon emissions is particularly interesting. The carbon tax does very well, as seen above, in curbing emissions, but, when we recycle the revenue, the economy is stimulated again and production in some industries increases.

In the same way that the more general recycling schemes would affect GDP more than specific taxes levied on a small tax base, we would expect that they would also affect $\mathrm{CO}_{2}$ emissions more. Recycling the tax revenue to industries that generate low-carbon electricity should not undo the good effects of the tax on carbon emissions, while a general stimulation of the economy should have a much larger effect. We see exactly this happening in Figure 8.

With no recycling of tax revenue, the total level of carbon emissions ends up 50.1 per cent below the baseline level, while recycling through a general tax on production decreases this effect to 40.7 per cent below base. Recycling the revenue through a subsidy on green-electricity generation maintains the initial positive result by changing emissions only slightly, namely to 52.5 per cent below the baseline.

Figure 8

Cumulative percentage change in carbon emissions of the no-recycling scenarios compared with three recycling scenarios (deviations from the baseline)

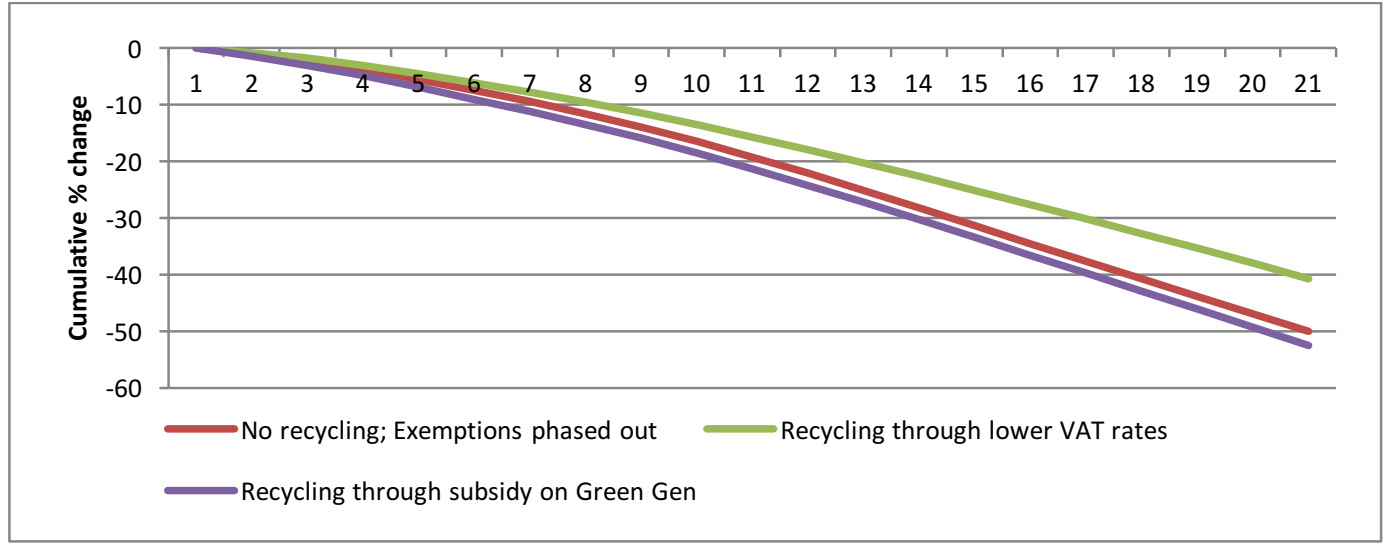




\subsubsection{The effects of the various recycling schemes on renewable electricity generation}

The penultimate effect involves recycling tax revenue on the production levels of green, or renewable, electricity. In Figure 9, we show the increase in the level of production of solar photovoltaic (PV) electricity above the baseline when we (i) levy a carbon tax but do not recycle the revenue (bottom line), and (ii) when we recycle the revenue through a subsidy on greenelectricity production. All the other recycling scenarios have very small effects on green generation - so small that the lines lie close to or on top of the no-recycling line. The effects of this recycling scenario on green generation are significant: without recycling, the tax revenue in respect of solar PV generation grows by 291 per cent above the baseline, while, with the subsidy on this section of industries, the output of solar PV grows by 376 per cent. The other green generators produce very similar results.

Figure 9

The effects of recycling carbon tax revenue through a production subsidy on the production of all green-electricity generators

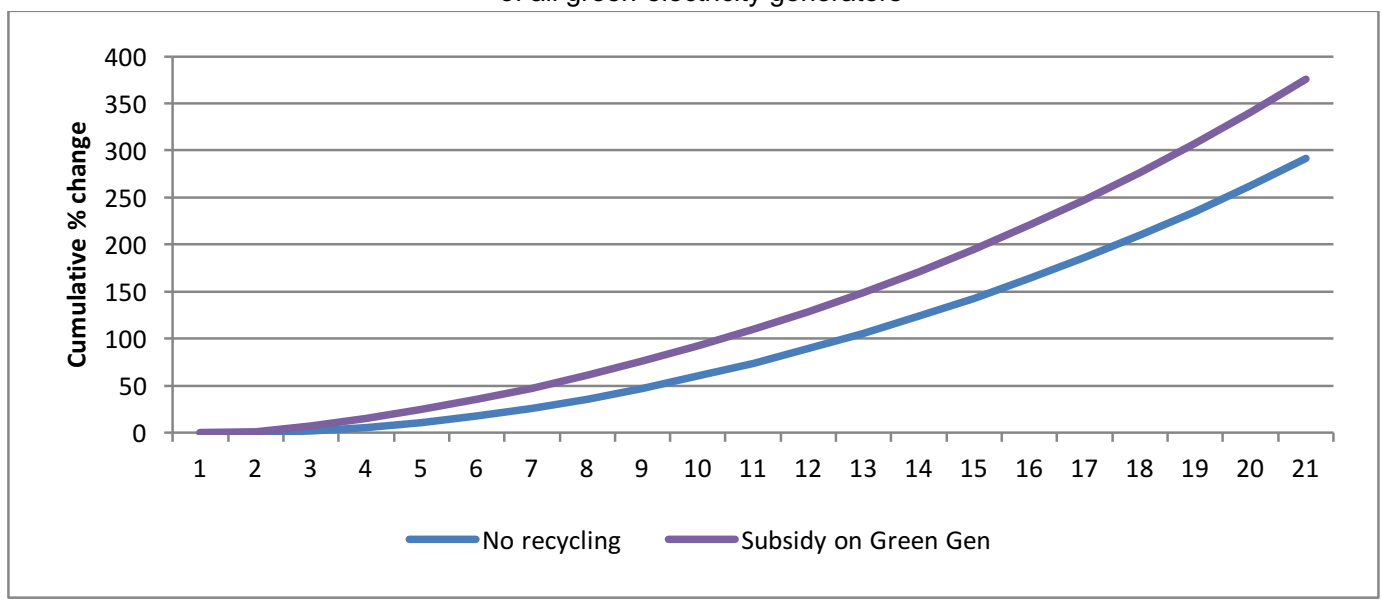

Figure 10

Percentage change in iron and steel production with the fuel input tax and various recycling options (all tax exemptions in place) (deviation from baseline)

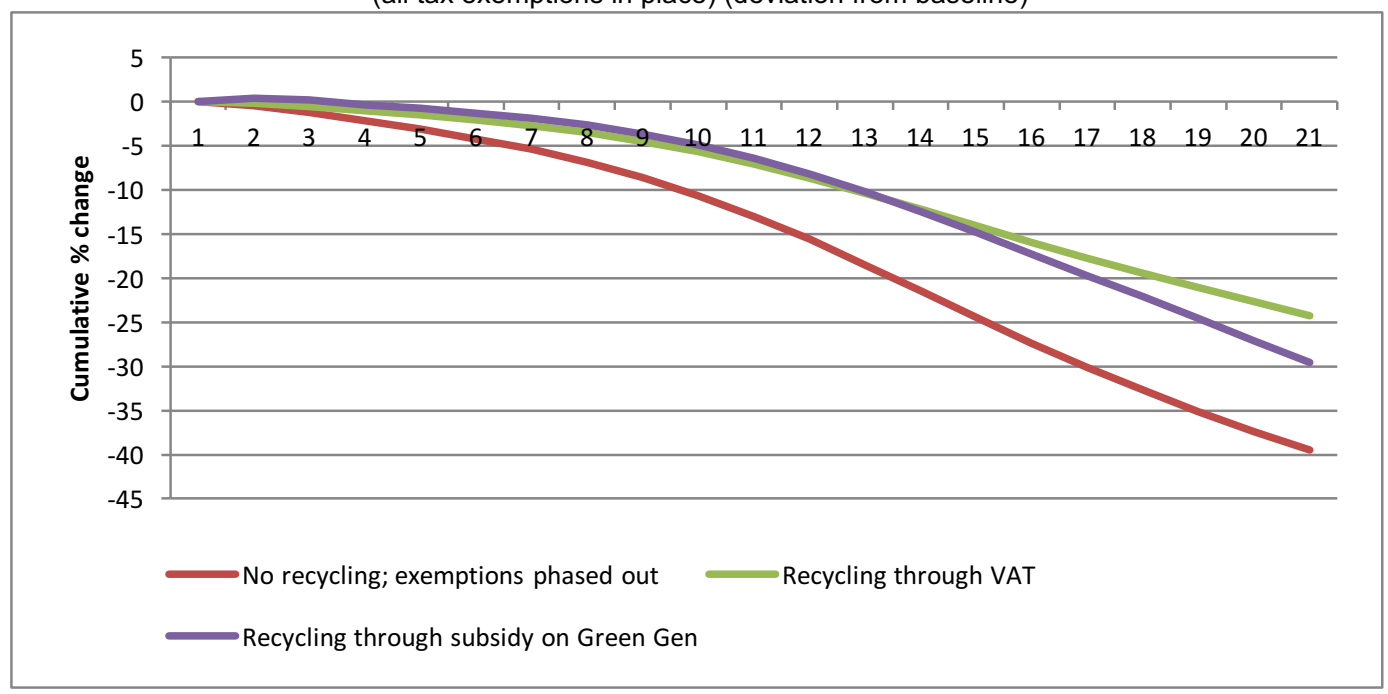




\subsubsection{Impact of taxes on the iron and steel industry, with and without recycling}

The various revenue recycling options' impact on the iron and steel industry was also modelled. The tax with all the exemptions phased out over the forecast period causes the industry to decline by 39.5 per cent in 2035 , but, if the tax revenue is recycled through a general subsidy on all production in the economy, the impact is significantly reduced to 24.2 per cent (green line in Figure 10 above). An insightful result is that, when recycling takes place through a production subsidy on green generators, the iron and steel industry is still severely affected by the tax (purple line). The iron and steel industry is electricity-intensive and the industry becomes much more expensive with the implementation of the tax.

\section{Conclusion and policy recommendations}

A 53-sector dynamic CGE model developed by the University of Pretoria's Department of Economics was used to assess the impacts of the carbon tax proposed by South Africa's National Treasury in May 2013 on the South African economy, which equates to $\mathrm{R} 120 / \mathrm{tCO}_{2}$-equiv., subject to a set of sector-specific exemptions.

Without the tax South Africa's baseline emissions rise from 564MtCO $1236 \mathrm{MtCO}_{2}$-equiv. for 2035 - an increase of $672 \mathrm{Mt}$ over the baseline period. Introducing the tax causes an anticipated reduction in $\mathrm{CO}_{2}$ emission growth by between 35 and 44 per cent, depending on the speed with which exemptions are removed and the manner in which carbon tax revenue is re-invested. These scenarios imply a cumulative reduction of between $1900 \mathrm{MtCO}_{2}$-equiv. and $2300 \mathrm{MtCO}_{2}$-equiv. relative to the baseline over the 2011 to 2035 modelling period, with the single-biggest (annual) reduction of between 190 and $250 \mathrm{MtCO}_{2}$-equiv. occurring in 2035 . The planned exemptions to various industries erode the positive effects on emissions significantly. The model suggests that South Africa's ambitious greenhouse gas mitigation strategy requires these exemptions be removed more quickly than is planned under the proposed tax.

All the tax and recycling scenarios reduce GDP growth, although the impacts are small. The range of cumulative reduction (between 2016 and 2035) varies, being between 1.5 and 6.5 per cent. This range is much less than the reduction in $\mathrm{CO}_{2}$ emissions mentioned above, implying that the $\mathrm{CO}_{2}$ emissions reductions effect outstrips that of the negative GDP effect by several orders of magnitude. The model suggests that the negative effects of the carbon tax on GDP growth can be minimised by specific revenue recycling approaches. The more production-oriented and the broader the recycling base, the better the recycling scheme is for the economy compared to recycling schemes that deliberately aim to protect consumption of basic goods.

The proposed carbon tax appears to have the greatest effect on the production of South Africa's fossil fuel intensive sectors, as is to be expected

In the model, total exports decrease as a result of the carbon tax due to a reduction in South Africa's competitiveness, but this result does not assume adoption of carbon pricing by South Africa's main trading partners. Iron and Steel and Other Manufacturing are the worst affected, and their exports could be lower than the baseline level by as much as 50 per cent. Other traditionally export-oriented industries, such as Other Metal Equipment, are lower than the baseline level by much less (17 per cent), while Other Mining is lower by 3 per cent.

The method of recycling chosen by the government is crucial for the macroeconomic and industry results. Recycling through a subsidy on green energy results in higher levels of energy produced through this technology, while recycling through a decrease in the general VAT rate is much better for the iron and steel industries and other export-oriented industries. It makes these industries more competitive in world markets, since a lower VAT rate lowers the production price indices. Our recommendation is that the government should not only try to protect certain industries through tax exemptions, but should also consider various recycling methods which might be more efficient in terms of the effects on the environment and the economy.

The analysis suggests that South Africa's proposed carbon pricing would contribute to South Africa's efforts to reduce its anthropocentric carbon dioxide emissions, but in isolation, is unlikely 
to be sufficient to achieve South Africa's PPD commitments (DEA 2011a \& b). Should South Africa embark on a carbon pricing strategy, it will have to adopt complementary measures to achieve its stated mitigation targets.

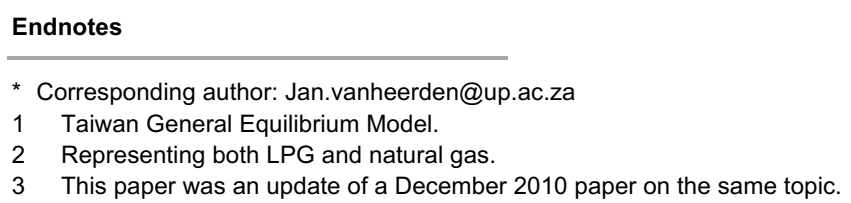

\section{Acknowledgements}

The authors acknowledge with thanks the guidance, support and inputs given by Dr Mike Toman and Dr Govinda Timilsina of the World Bank. The participation and inputs of Mr Cecil Morden, Mr Peter Janoska and Dr Memory Machingambi of the South African National Treasury in the study are also gratefully acknowledged. The authors also acknowledge the financial support of the World Bank's Partnership for Market Readiness on Climate Change Mitigation programme.

\section{References}

ADAMS, P.D., DIXON, J., GIESECKE, J. \& HORRIDGE, J.M. 2014. MMRF5: Monash multi-regional forecasting model: A dynamic multi-regional model of the Australian economy. Available on request from the Centre of Policy Studies. Previously published as CoPS General Paper No. G-223.

ALTON, T., ARNDT, C., DAVIES, R., HARTLEY, F., MAKRELOV, K., THURLOW, J. \& UBOGU, D. 2014. Introducing carbon taxes in South Africa. Applied Energy, 116:344-354.

BLIGNAUT, J.N., MABUGU, R.M. \& CHITIGA-MABUGU, M.R. 2005. Constructing a greenhouse gas emissions inventory using energy balances: The case of South Africa, 1998. Journal of Energy in Southern Africa, 16(3):105-116.

BOHLMANN, H.R., DIXON, P.B., RIMMER, M.T. \& VAN HEERDEN, J.H. 2015. The impact of the 2014 platinum mining strike in South Africa: An economy-wide analysis. Economic Modelling, 51:403-411.

CEPII. 2012. The great shift: Macroeconomic projections for the world economy at the 2050 horizon. CEPII Working Paper 2012-03. Paris: Centre D'Etudes Prospectives Et D'Informations Internationales.

DEA (DEPARTMENT OF ENVIRONMENTAL AFFAIRS). 2009. Greenhouse gas inventory South Africa: 1990-2000. Pretoria: Department of Environmental Affairs.

DEA (DEPARTMENT OF ENVIRONMENTAL AFFAIRS). 2011a. National Climate Change Response White Paper. Pretoria: DEA. Available at:

http://www.environment.gov.za/sites/default/files/legislations/national_climatechange_response_whitepaper. pdf.

DEA (DEPARTMENT OF ENVIRONMENTAL AFFAIRS). 2011b. Defining South Africa's peak, plateau and decline greenhouse gas emission trajectory. Explanatory note. Pretoria: DEA.

DED (ECONOMIC DEVELOPMENT DEPARTMENT). 2011. Green economy accord. Pretoria: DED.

DOE (DEPARTMENT OF ENERGY). 2013. Integrated resource plan for electricity 2010-2030: Updated report, November 2013. Pretoria: Department of Energy.

DEVARAJAN, S., GO, D.S., ROBINSON, S. \& THIERFELDER, K. 2009. Tax policy to reduce carbon emissions in South Africa. Policy Research Working Paper 4933. World Bank.

DIXON, P.B. \& RIMMER, M.T. 2002. Dynamic general equilibrium modelling for forecasting and policy: A practical guide and documentation of MONASH. Amsterdam: North-Holland.

DIXON, P.B. \& RIMMER, M.T. 2005. Reducing the barriers to entry in dynamic CGE modelling. Paper Prepared for the 8th Annual Conference on Global Economic Analysis, Lübeck, Germany.

DIXON, P.B., KOOPMAN, R.B. \& RIMMER, M.T. 2013. The MONASH style of CGE modelling. In: P.B. Dixon \& D.W. Jorgenson (eds.) Handbook of computable general equilibrium modelling. Amsterdam: NorthHolland.

HARRISON, W.J. \& PEARSON, K.R. 1996. Computing solutions for large general equilibrium models using GEMPACK. Computational Economics, 9:83-127. 
HINCHY, M. \& HANSLOW, K. 1996. The MEGABARE model: Interim documentation. Canberra: Australian Bureau of Agricultural and Resource Economics.

HORRIDGE, J.M., MEERAUS, A., PEARSON, K.R. \& RUTHERFORD, T.F. 2013. Solution software for CGE modelling. In P.B. Dixon \& D.W. Jorgenson (eds.) Handbook of computable general equilibrium modelling. Amsterdam: North-Holland.

IMF (INTERNATIONAL MONETARY FUND). 2016. World economic outlook, April 2016. Washington DC.

KEARNEY, M. 2008. Modelling the impact of $\mathrm{CO}_{2}$ taxes in combination with the long-term mitigation scenarios on emissions in South Africa using a dynamic computable general equilibrium model. University of Cape Town, Energy Research Centre.

NATIONAL TREASURY. 2013. Carbon tax policy paper: Reducing greenhouse gas emissions and facilitating the transition to a green economy. Pretoria: National Treasury.

NATIONAL TREASURY. 2014. Carbon offsets paper-Published for public comment. Available at: http://www.treasury.gov.za/public\%20comments/CarbonOffsets/2014042901\%20-

$\% 20$ Carbon\%20Offsets\%20Paper.pdf [accessed January 2016].

NATIONAL TREASURY. 2015. Draft Carbon Tax Bill. Pretoria: National Treasury. Issued on 2 November 2015 and introduced in the National Assembly by the Minister of Finance.

NATIONAL TREASURY. 2016. Budget review 2016. Pretoria: National Treasury. Published on 24 February 2016. Available at: www.treasury.gov.za [accessed March 2016].

PAUW, K. 2007. Economy-wide modelling: An input into the long term mitigation scenarios process. LTMS Input Report 4. Cape Town, Energy Research Centre.

SEYMORE, R., INGLESI-LOTZ, R. \& BLIGNAUT, J.N. 2014. A greenhouse gas emissions inventory for South Africa: A comparative analysis. Renewable \& Sustainable Energy Reviews, 34:371-379.

StatsSA (STATISTICS SOUTH AFRICA). 2014. Gross domestic product, fourth quarter 2013. Statistical Release P0441. Pretoria: Statistics South Africa.

STERN, N. 2008. The economics of climate change. Richard T. Ely lecture published in American Economic Review, 98(2):1-37.

VAN HEERDEN, J.H, GERLAGH, R., BLIGNAUT, J.N, HORRIDGE, J.M., HESS, S., MABUGU, R.M \& MABUGU, M.R. 2006. Searching for triple dividends in South Africa: Fighting $\mathrm{CO}_{2}$ pollution and poverty while promoting growth. The Energy Journal, 27(2):113-141.

VAN HEERDEN, J.H., BLIGNAUT, J.N. \& HORRIDGE, M. 2008. Integrated water and economic modelling of the impacts of water market instruments on the South African economy. Ecological Economics, 66(1):105-116.

WAGNER, G. \& WEITZMAN, M.L. 2015. Climate shock: The economic consequences of a hotter planet. Princeton University Press. 


\section{Appendix A}

Summary of the energy database used in the CGE model

Table A1

Energy consumption (in TJ) by fuel, and effective tax rate (R/TJ) by fuel and per sector, after making provision for the tax-free exemption thresholds

\begin{tabular}{|c|c|c|c|c|c|c|c|}
\hline & \multicolumn{4}{|c|}{ Fuel consumption (TJ) (2011) } & \multicolumn{3}{|c|}{$\begin{array}{l}\text { Effective tax rate (R/TJ) (2016) } \\
\text { (after applying the tax-free } \\
\text { thresholds) }\end{array}$} \\
\hline & Coal & Gas & Petroleum & Total & Coal & Gas & Petroleum \\
\hline \multicolumn{8}{|l|}{ SIC 1 - AGRICULTURE } \\
\hline Agriculture & 289 & 27027 & 36439 & 63755 & 0 & 0 & 0 \\
\hline Forestry & - & 3293 & 4426 & 7719 & 0 & 0 & 0 \\
\hline Fishing & - & 354 & 499 & 853 & 0 & 0 & 0 \\
\hline \multicolumn{8}{|l|}{ SIC 2 - MINING } \\
\hline Coal mining & 589 & 31070 & 18013 & 49671 & 2294 & 1529 & 1741 \\
\hline Metal-ores extraction & 16606 & 8410 & 7295 & 32311 & 3442 & 2294 & 2612 \\
\hline Crude-gas extraction & 1186 & 1773 & 478 & 3436 & 3442 & 2294 & 2612 \\
\hline Other mining & 36195 & 54108 & 14577 & 104880 & 3442 & 2294 & 2612 \\
\hline Electric energy and gas & 14737 & 6 & 327 & 15070 & 3442 & 2294 & 2612 \\
\hline \multicolumn{8}{|l|}{ SIC 3 - MANUFACTURING } \\
\hline Food & 2512 & 1163 & 28 & 3703 & 3442 & 2294 & 2612 \\
\hline Beverages and tobacco & 391 & 21 & - & 412 & 3442 & 2294 & 2612 \\
\hline Textiles and footwear & 1285 & 410 & - & 1695 & 3442 & 2294 & 2612 \\
\hline Wood and paper & 921 & 128 & 26 & 1075 & 3442 & 2294 & 2612 \\
\hline Print and publication & 2057 & 5936 & 1068 & 9061 & 3442 & 2294 & 2612 \\
\hline Coke oven & 62454 & 94566 & 1358 & 158378 & 3442 & 2294 & 2612 \\
\hline Petroleum refineries & 145726 & 535866 & 5428 & 687019 & 3442 & 2294 & 2612 \\
\hline Nuclear fuels & 1299 & 22789 & 4806 & 28893 & 3442 & 2294 & 2612 \\
\hline Chemical & 6197 & 108714 & 22925 & 137836 & 2294 & 1529 & 1741 \\
\hline Rubber & 928 & 213 & 965 & 2106 & 2294 & 1529 & 1741 \\
\hline Plastic & 185 & 1705 & 224 & 2114 & 2294 & 1529 & 1741 \\
\hline Glass & 291 & 6395 & - & 6686 & 2294 & 1529 & 1741 \\
\hline Cement & 8163 & 16364 & 78 & 24604 & 2294 & 1529 & 1741 \\
\hline Other non-metal & 8843 & 18452 & 87 & 27383 & 2294 & 1529 & 1741 \\
\hline Iron and steel & 131276 & 57824 & 108953 & 298053 & 2294 & 1529 & 1741 \\
\hline Other metal equipment & 9001 & 50119 & 13294 & 72414 & 3442 & 2294 & 2612 \\
\hline Electricity machinery & 128 & 102 & 2066 & 2297 & 3442 & 2294 & 2612 \\
\hline Radio and TV & 19430 & 20726 & - & 40156 & 3442 & 2294 & 2612 \\
\hline Transport equipment & 7 & 272 & 5 & 284 & 3442 & 2294 & 2612 \\
\hline Furniture & 2121 & 1444 & - & 3565 & 3442 & 2294 & 2612 \\
\hline Other manufacturing & 1165 & 133334 & 1064 & 135562 & 3442 & 2294 & 2612 \\
\hline \multicolumn{8}{|c|}{ SIC 4 - ELECTRICITY, GAS AND WATER } \\
\hline Coal-fired power generation & 2412161 & - & 39985 & 2452146 & 4589 & 3059 & 3483 \\
\hline Nuclear power generation & - & - & 2496 & 2496 & 4589 & 3059 & 3483 \\
\hline Wind power generation & - & - & 252 & 252 & 4589 & 3059 & 3483 \\
\hline Hydropower generation & - & - & 3505 & 3505 & 4589 & 3059 & 3483 \\
\hline Solar PV power generation & - & - & 504 & 504 & 4589 & 3059 & 3483 \\
\hline Solar CSP power generation & - & - & 252 & 252 & 4589 & 3059 & 3483 \\
\hline Gas power generation & - & 1168 & 504 & 1673 & 4589 & 3059 & 3483 \\
\hline Other generation & 12120 & - & 2496 & 14616 & 4589 & 3059 & 3483 \\
\hline Electricity distribution & - & - & 12492 & 12492 & 4589 & 3059 & 3483 \\
\hline Water & 12710 & 48 & 388 & 13146 & 3442 & 2294 & 2612 \\
\hline
\end{tabular}




\begin{tabular}{|c|c|c|c|c|c|c|c|}
\hline \multicolumn{8}{|l|}{ SIC 5 - CONSTRUCTION } \\
\hline Construction & - & 6888 & 10509 & 17397 & 3442 & 2294 & 2612 \\
\hline \multicolumn{8}{|c|}{ SIC 6 - WHOLESALE \& RETAIL TRADE AND HOTEL \& RESTAURANT SERVICES } \\
\hline Trade & - & - & 44780 & 44780 & 3442 & 2294 & 2612 \\
\hline Hotel and restaurants & 3029 & 248 & 2804 & 6082 & 3442 & 2294 & 2612 \\
\hline \multicolumn{8}{|c|}{ SIC 7 - TRANSPORT, STORAGE AND COMMUNICATION SERVICES } \\
\hline Transport services & 12110 & 17034 & 782716 & 811860 & 3442 & 2294 & 2612 \\
\hline $\begin{array}{l}\text { Post and tele- } \\
\text { communication services }\end{array}$ & 411 & 578 & 26556 & 27545 & 3442 & 2294 & 2612 \\
\hline \multicolumn{8}{|c|}{ SIC 8 - FINANCIAL AND BUSINESS SERVICES } \\
\hline Financial services & - & - & 16391 & 16391 & 3442 & 2294 & 2612 \\
\hline Insurance services & - & - & 1874 & 1874 & 3442 & 2294 & 2612 \\
\hline Other financial services & - & - & 978 & 978 & 3442 & 2294 & 2612 \\
\hline Real estate & - & - & 30498 & 30498 & 3442 & 2294 & 2612 \\
\hline Other business services & - & - & 17275 & 17275 & 3442 & 2294 & 2612 \\
\hline \multicolumn{8}{|c|}{ SIC 9 - COMMUNITY, SOCIAL AND PERSONAL SERVICES } \\
\hline General government & 6025 & 3067 & 12737 & 21828 & 3442 & 2294 & 2612 \\
\hline Education & 62 & 277 & 421 & 760 & 3442 & 2294 & 2612 \\
\hline Health & 3109 & 13873 & 21013 & 37995 & 3442 & 2294 & 2612 \\
\hline Other services & 462 & 3916 & 5962 & 10340 & 3442 & 2294 & 2612 \\
\hline Total & 1804330 & 2055578 & 1607768 & 5467676 & - & - & - \\
\hline
\end{tabular}

\section{Appendix B}

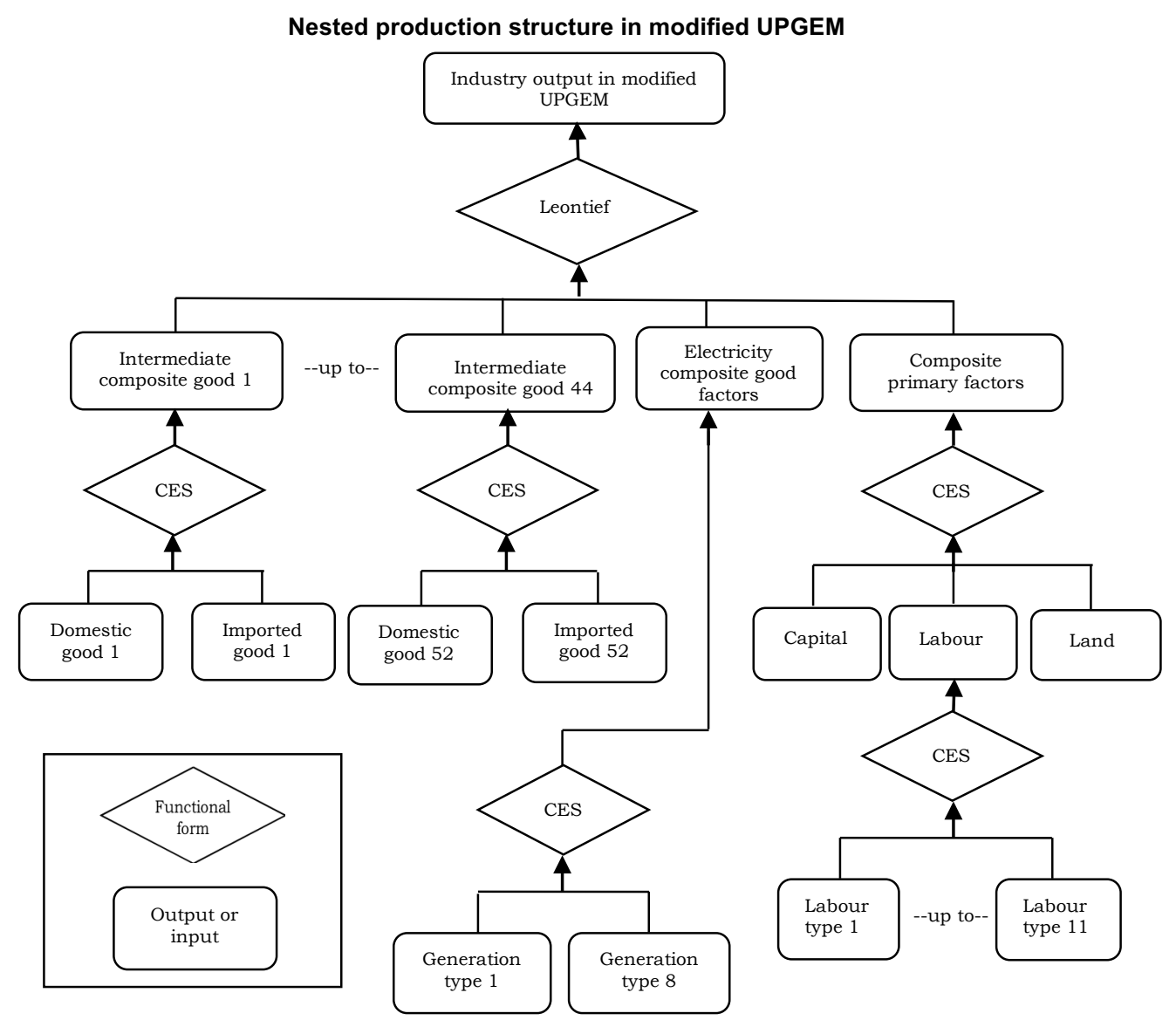

